\title{
Enhancing Engagement and Early Literacy Through Music: Perspectives from Head Start Teachers
}

\author{
Pothein Vaiouli $^{1^{*}} \quad$ Kharon Grimmet ${ }^{2}$ \\ 1.Center for Applied Neuroscience, University of Cyprus, Kallipoleos 75, Nicosia, Cyprus \\ 2.College of Education, College of Education, Purdue University, 100 N. University St., West Lafayette, IN \\ 47907 \\ * E-mail of the corresponding author: pvaiouli@gmail.com
}

\begin{abstract}
Early literacy and engagement are critical outcomes that can be fostered by early childhood educators in their classrooms through intentional implementation of age-appropriate and contextually relevant learning experiences. This study examines the implementation of a music intervention model developed to enhance engagement and early literacy development of young children within inclusive early childhood settings. The intervention, which incorporated daily music activities embedded in a Head Start classroom's daily routines, was implemented for six months by the classroom teachers. Qualitative data on the children's actions allowed for an in-depth exploration of the role of music as the mediator for engaging teaching moments that allow learning to evolve as an integral part of children's routines. Further, the perspectives of Head Start teachers' on the use of the music as an engaging context to promote engagement and early literacy development were explored. Finally, possible challenges of implementing such a music intervention model in the classroom and the role of music as an asset-building strategy that can meet the educators' goals and the children's needs are discussed.
\end{abstract}

Keywords: music, early literacy, inclusion, preschool, engagement

DOI: $10.7176 / \mathrm{JEP} / 11-14-02$

Publication date:May $31^{\text {st }} 2020$

\section{Introduction}

Young children begin their journey of learning to read and write long before they enter formal schooling. Early literacy emerges from a developmental process that begins at birth, as children participate in everyday activities and are exposed to environmental sounds, language, vocabulary, and concepts of print (Goldstein, 2011). Through this process, young children acquire foundational early literacy skills that develop progressively during their preschool years and are important for later reading success (Dixon-Krauss, Januszka, and Chae, 2010; Whitehurst and Lonigan, 2001).

Early literacy includes learning code-based and meaning-focused skills (Whitehurst and Lonigan, 1998). Systematic instruction of code-based and meaning-focused skills has the potential to build the skills a child needs to succeed in a literate world (Dixon-Krauss, Januszka, and Chae, 2010) as the children make sense of written material and comprehend stories and narratives. Supportive adults who systematically provide feedback, create conditions that extend children's curiosity, and expand children's language environment are essential for children's language development and learning (Mol and Neuman, 2014; Neuman and Carta, 2011). That way the transmission of early literacy skills is fostered within an environment that provides diversity in the language practices and exposes children to broad vocabulary and language experiences (Neuman, Kaefer, and Pinkham, 2018).

This is especially important for children growing up in low-income families and/or children having English as a second-language. A large body of research indicates a highly predictable relationship between lower socioeconomic environments (low SES) and learning difficulties in schools (Catts, Fey, Tomblin, \& Zhang, 2005; Duncan \& Seymour, 2000; Massey, 2007; McCardle, Scarbough, \& Catts, 2001). Additionally, the IES research synthesis on Early Intervention and Early Childhood Education (Diamond, Justice, Siegler, and Snyder, 2013) has indicated that growing up in low-income environments and having a developmental disability may lead to elevated risks for adverse educational outcomes along with significant challenges for children in their language, literacy, and social skills.

Head Start schools serve children from challenging environments and have a greater percentage of children with disabilities than found in the overall population (U.S. Department of Health and Human Services, 2017). As such, this study aimed to explore the implementation of a content-rich, music intervention, in which skills are learned through meaningful, music activities to help all children acquire knowledge and dispositions that build the foundation of early literacy skills. The study is based on the premises that engagement and learning occur in a reciprocal process, generated within the context of relationships that young children form with peers and adults in their environments (Rogoff, 1990). Therefore, a child's early learning experiences can be enriched and further developed through his/her exposure to engaging, collaborative activities in early childhood settings (Neuman, 2006). Such activities may provide background knowledge and the context to support the development of early literacy skills as children participate in everyday classroom activities (Goldstein, 2011). In the following parts a 
detailed literature review will present connections between music, engagement, and learning along with the main goals of this study.

\section{Literature Review}

Studies have shown the effectiveness of embedding learning opportunities for young children within the contexts of natural setting and ongoing play (Ridley, McWilliam, Oates, 2000; Warren and Kaiser, 1986; Warren, Yoder, Gazdag, Kim, and Jones, 1993). Engaging activities present multiple opportunities for arousing children's attention, curiosity, and motivation, and for addressing a range of interests, preferences, and personal learning styles (Horn and Banerjee, 2009). For the purpose of this paper, engagement is defined as the children's interaction with peers, adults, and materials in a developmentally and contextually appropriate matter; that is, in a manner appropriate for the child's developmental age and abilities, for the activity, and the situation (McWilliam and Bailey, 1995; McWilliam and Bailey, 2000). Engaging teaching moments embedded in the children's natural environment allow for learning to evolve as an integral part of the children's culture, routines, and actions in their school setting (McWilliam and Casey, 2008; Powell, Burchinal, File, Kontos, 2008).

\subsection{Music and Engagement}

Music has been identified as an essential element of young children's early development. Joint music making functions as a regulator for children's behaviours and their emotional states and it holds a strong role in shaping family cultures, rituals, and relationships among young children and their social environments (Barrett, 2006). Engaging in music is a multi-faceted activity (Young and Ilari, 2012; Welch and McPherson, 2012) that can serve as a scaffold that fosters children's participation, encourages self-expression, and the practice of academic skills (Anvari, Trainor, Woodside, and Levy, 2002). Songs and musical games provide opportunities for children to coconstruct their cultural milieu and to develop new skills in relation to their experiences and their environment (Barrett, 2006; Custodero, 2006; Lessard and Bolduc, 2011; Palmer, 2004; Pound and Harrison, 2003). Also, when embedded in the classroom routines, music activities can offer a predictable structure, repetitive language, kinaesthetic experiences, and a story line that support all children's engagement and independent learning (Hallam, 2010; Vaiouli et al., 2015). At the same time, music through the form of singing, playing, listening and responding enhance participation and collaboration within the school setting and help children acquire a sense of belonging in the classroom (Heyworth, 2013; Vaiouli \& Ogle, 2016).

\subsection{Music and Early Literacy Skills}

An increasing body of research illustrates that participation to musical activities can positively impact children's cognitive and academic growth (Isenberg and Jalongo, 2001; Young, 2003; Youth Music, 2007). Music interventions have been noted for their potential to teach children important skills related to early literacy (Darrow et al., 2009; Lessard and Bolduc, 2011; Vaiouli et al.,2015). Singing songs showed promising results in relation to expressive language and vocabulary development (Young, 2003). Other studies examined children's musical aptitude, sound sensitivity, and sound manipulation in language and showed a correlation between music interventions and phonological awareness skills, along with reports about the children's enthusiasm and higher levels of engagement during the activities (Anvari, Trainor, Woodside, and Levy, 2002; Darrow et al., 2009; Register, 2001). Specific music components, such as timing, pacing, and pausing, are all important components of interactive games that foster child independence and mastery of new skills in a fun and age-appropriate way (Hallam, 2010). Finally, music activities are shown to provide an important context for meaning-focused early literacy skills, such as retention, recall of information, vocabulary development, and making inferences through discussion of the lyrics and the narrative in each song (Hallam, 2010). Through music and sounds, children can act as their own agents of learning (Custodero, 2002).

Collectively, these findings suggest that early childhood educators may use music activities as an opportunity to engage in collaborative activities with children, scaffold children's levels of participation, and elaborate upon the children's action with an academic focus. However, there have been few studies exploring specific ways in which music activities can be intentionally implemented within early childhood settings with the aim to provide an additional layer for engagement between adults and other peers in the room while fostering children's early literacy development. More importantly, enough studies have shown that early childhood educators sometimes feel they are not competent enough to use music together with children in their classrooms (Hallam et al., 2009; Hennessy, 2000; Ruddock and Leong, 2005; Russell-Bowie, 2009; Seddon and Biasutti, 2008; Stunell, 2010; Young, 2009).

Taking these key points under consideration, this study aimed to: 1) Explore the potential of implementing a music intervention model in a Head Start school's daily routines; 2) Better understand how the implementation of such an intervention model may promote young children's engagement and early literacy abilities and, 3) Gain the perspectives of early childhood educators on utilizing music as an engaging, instructional tool/context in a Midwest Head start classroom. 


\section{The music intervention}

\subsection{The Music intervention handbook}

To facilitate and enhance the implementation of musical activities in the classroom, the researcher put together a collection of music activities, the Music for Engagement and Learning handbook (MELody) which she shared with the participating teachers in the study. MELody included actions songs, music and movement activities, nursery rhymes, and music story-books to be embedded during circle-time and overall throughout the children's day. Also, MELody included a section in which the researcher had identified components within the music activities, which aligned with engagement actions and early literacy goals. For example, when singing in rote, children may learn to listen to each-other, wait for their turn, collaborate within small groups, and identify the ending sounds of a word. The end product was a collection of suggested musical activities and materials that could be implemented in the classroom, in a form of a handbook rather than a comprehensive curriculum. Table 1 presents an example of the main structure of MELody.

\subsection{The teacher-researcher collaboration}

An important focus of this study was for the teacher to take ownership of the music intervention, as opposed to perceiving it as an external initiative. The teacher's sense of self-efficacy and intentionality when using music were key for facilitating engaging, learning experiences during music interactions. Also, we valued the teachers as active participants in identifying the content (the knowledge domain) and the activities to be embedded in their classroom routines for supporting children's learning. As such MELody was initially shared with the classroom teacher as a set of suggested activities, which the teacher then modified and enriched according to the thematic teaching of the center and her own priorities and understanding of the students' needs. For that purpose, there were ongoing discussions between the researcher and the classroom teacher during which the teacher was encouraged to identify her own teaching and learning goals, music activities they were already used in the classroom, and possible ways of intentionally using them to scaffold and extend children's learning. Overall, throughout the intervention, the researcher and the teacher cooperated closely, as partners in an iterative process for the implementation of the music activities in the classroom.

\section{Methodology}

A qualitative research design can enhance understanding of the elements of a phenomenon and its attributes within the context in which they are observed (Brantlinger, Jimenez, Klinger, Pugach, and Richardson, 2005). Specifically, a descriptive case study (Yin, 2003) was implemented to reflect on questions about why and how music may be used in the classroom to engage children and promote early literacy development, in relation to the teacher's perspectives on the use of music and the real classroom setting. These perspectives were used to understand, explain, and discuss the teacher's choices on the use of a music as a means to enhance children's growth.

\subsection{Participants and Setting}

The study took place in a classroom of a rural Head Start program. The program was chosen because of its unique profile in terms of the population they serve. Specifically, the program serves largely Caucasian and Englishspeaking children and also bi-racial and bilingual families over a large geographic rural area of the state. Within the specific community most jobs were based in either agriculture or extractive industries. The classrooms were located in a community building and the program had a history of collaboration with schools in the area as well as other educational and human service organizations.

After approval of the Institutional Review Board, one teacher, her teaching assistant, and their children ( $\mathrm{n}=17)$ who signed the consent forms, volunteered to participate in the study for the duration of four months. As part of the selection criteria, the participating teacher was required to have: (a) at least an Associate Degree E.C.E (as required by the Head Start program they serve); and (b) no prior music training or academic background in music education. The participating teacher was Caucasian and from the community. She had a total of ten years of experience in early childhood education; six of those years had been in her current position. The teacher assistant (also, Caucasian and from the community) had eight years of experience, all of them in her current position.

Children's age ranged from 3 to 5 years old. We worked in a class that had a total of seventeen children, eleven boys and six girls. 15 children (88\%) were Caucasian and 2 children (12\%) were bi-racial. Four of the seventeen total children in the class $(24 \%)$ were identified with a special need (developmental delay, speech and language impairment, attention deficit and/or hyperactivity) and received special services one day per week.

\subsection{Procedures}

Prior to implementing MELody in the classroom, the researcher met with the classroom teacher and the teacher assistant for three weeks in a row and shared with her the theoretical tenets on the potential of using music to promote engagement and early literacy in early childhood classrooms. During this time, the researcher presented the MELody handbook both orally and with written examples. Together the teacher and the researcher discussed 
strategies for aligning the music activities with the centre's weekly themes and the teacher's teaching goals so that music could be embedded in the classroom's daily routines. The researcher got feedback from the teacher on the chosen music activities and the targeted early literacy skills and then, she revised the activities according to the teacher's comments and thoughts. MELody in its final form, included music activities to promote engagement and early literacy abilities for young children through interactive games, voice/sound explorations accompanied with hand-drums (one for each child), folk songs/dance, short improvisational parts, and storybook reading, all intended to enhance interactions and the act of learning for children in the class.

The participating teacher and the teacher assistant collaborated with the researcher for a period of six months. During this time, the teacher chose one singing activity and one action music activity (as they were outlined in MELody) and she incorporated them daily in her classroom routines for 10-15 minutes. Every week, music was embedded during the morning circle time to reinforce the content of the larger group activities, and then the teacher or the children brought up again the music experience during center-work and/or during recess. At the end of each week, the classroom teacher filled in the teacher's log, which then she shared with the researcher.

\subsection{The Role of the Researcher}

During the implementation of MELody, the researcher visited the classroom twice a week and spent time as a participant-observer in the classroom. The researcher aimed to develop and negotiate a relationship with the teacher and the children in the group (Graue and Walsh, 1995) based on mutual respect so that both the children and the teacher would willingly engage in the research process (Sumsion, 2004). During her weekly visits, the researcher participated in the classroom routines, interacted with the children, kept notes, and spent some time at the end of the day to discuss with the teacher on the music she used. During that time, the teacher and the researcher engaged in a dialogue on the children's responses and the role of music in the classroom, they shared new musical ideas based on the children's participation, and they identified together moments of success and points for improvement.

\section{Data Collection}

\subsection{Observation and Field Notes}

To provide an in-depth description of the process of using music intentionally as a teaching tool/context in the classroom, the researcher gathered data through a variety of sources. The researcher followed the Head Start teacher for the duration of the six months and assumed the role of a participant-observer, as described above. Approximately, 85 hours of observation data were collected from the teacher's classroom. During her visits, the researcher kept detailed field notes (recorded on the spot and expanded after the visit), took pictures and engaged in ongoing conversations with the classroom teacher and the children on the use of music to deepen her understanding on the process of using music to enhance classroom routines. Also, audio/visual materials related to the children's interactions during music activities in the classroom and during free play periods were collected.

\subsection{Semi-Structured Interviews}

The field notes were enriched through two semi-structured interviews with the early childhood educator of the classroom, one conducted at the beginning and one at the end of the collaboration with the researcher. The semistructured interviews were conducted individually at a time and place convenient to the teacher. The questions focused on the teacher's beliefs about early literacy development, her overall goals for her group of students, and ways she used music in her classroom. Also, during this time, the teacher was asked to share her thoughts on priorities for children's needs and her perspectives on the use of music beyond recreational purposes in relation to the overall feasibility of implementing music in her daily routines.

\subsection{Weekly Logs}

Finally, the teacher provided the researcher with her weekly logs on the use of music in the classroom. The logs included an overview of the activities implemented in the classroom for the week and they had guiding questions about the implementation of these music activities, the teacher's rationale for choosing the, challenges and moments of success as identified by the teacher, and the teacher's reflections on the students' responses to music. At the end of the log, there was space for the teacher to share ideas for improvement and any adaptations she would like to see, based on her experience with using music.

\section{Results}

The researcher used connecting strategies (Maxwell, 2005) to understand the data in their wholeness and identify relationships between the various data sources: semi-structured interviews, informal ongoing conversations with the teacher and the teacher assistant, notes from the logs, and field notes. For that purpose, all interviews were transcribed along with all the audio and video materials and then data from all sources were compiled into one file. The researcher implemented thematic analysis to identify, analyse and report patterns within the data set (Braun 
and Clarke, 2006). Initial codes were generated, classified into potential themes as the analysis evolved and then the researcher reviewed and refined themes to produce the final report, presented in the results section. A second researcher, experienced in qualitative research, served as a peer debriefer and underwent the same process on a random part of the transcripts ( $40 \%$ of it) to ensure reliability of the generated themes and confirm the researcher's accuracy of quotes, coding, and interpretation of the source data. Finally, to ensure trustworthiness and credibility of the research, the researcher presented the final themes to the teachers to do a member check and verify the content presented.

The qualitative analysis of the data revealed the following themes, which are presented below (all names in this section are pseudonyms to protect anonymity of the participants):

\subsection{Instruction, Engagement, and Intentionality in the Classroom Setting}

It was evident from the observations that Ms Judith, the classroom teacher, and her assistant, Ms Jenna, had a great collegial relationship as they worked closely together to support the children in their classroom. Through interviews and collaboration sessions with the researcher, both Ms Judith and Ms Jenna shared their vision to ensure their classroom was a warm, inviting place for the children. Pieces of each child's artwork and writing samples decorated the classroom walls. Each name tag was filled full of engaging colours to match the chairs and tables, which signified different work areas: red for colouring and play-doh, yellow for writing and exploring written materials. A red sofa was stationed in the book area so the children could comfortably explore the variety of literature that surrounded the reading nook. All materials were strategically placed throughout the classroom to ensure that each child could easily access whatever he/she needed.

Both Ms Judith and Ms Jenna enjoyed music activities and had already noticed the calming effect it could have on children's actions. A CD player was the focal point of the centre of the room and a variety of small percussions and stick instruments were used during circle time. The morning circle did not always incorporate the use of music of activities, but Ms Judith would prepare a random CD full of calming melodies in cases her class became uneasy or over active. She said that she used music because "children calm down". Also she had a selection of movement and singing activities and she often danced along with the children at the end of the day.

In relation to teaching early literacy skills Ms Judith had initially expressed concerns about using music during large group instructional time. She shared with the researcher that "children [should] enjoy music" and experience it as an "outlet for joy and entertainment during the day." She continued, noting that her students were missing [joy and fun] in their everyday lives [due to environmental stressors of poverty]. She expressed that her focus was to provide opportunities for her students to play and just "be a kid." She believed her role and responsibility as far as early literacy was to support her students in "...familiariz[ing] [themselves] with the use of books and to appreciate them and take care of them...".However, she believed that "repetition is boring" and noticed that her students preferred hands-on activities instead of only "...handling books and practicing letters."

Ms Judith seemed to equate literacy with alphabet knowledge (that is to identify the letters through flash cards) and name writing (writing and decorating their names). One such example was that she repeated names and alphabet letters to the children throughout daily routines. Many of the students seemed to grow impatient as they began moving around the carpet and picking on one another. Ms Judith responded to the students' impatience by removing them from the circle. Probably, the students' behaviours reinforced her belief that early literacy activities may be boring.

\subsection{Music Fostering Engagement and Early Literacy Abilities}

As the music intervention progressed, the classroom teachers began to observe subtle changes on the children's participation. One day, Ms Judith shared with the researcher about the use of music during circle time: "Music and dancing is how you feel but adding the literacy part to it...it makes it work for them as well and makes it fun". Embedding songs throughout the day helped Ms Judith to “...catch their (children's) attention on certain things"...like yesterday they picked a book... and they enjoy it a little bit more, not just singing a song, working on letters and sounds made it a little bit of a learning experience".

During the intervention, both Ms Judith and Ms Jenna had opportunities to explore other ways of using music to promote learning and engagement during instructional time. Halfway through the intervention Ms Judith noted in her journal: "the beat made it easy to remember and I liked the rhyming practice...rhythm beat using hands...repeating the most difficult areas and being interactive". Going on Ms Judith elaborated on the process of using music throughout the day: "I look at the whole picture of it as different songs in different ways". Embedding songs throughout the day helped Ms Judith to “...catch their (children's) attention on certain things"...like yesterday they picked a book... and they enjoy it a little bit more, not just singing a song, working on letters and sounds made it a little bit of a learning experience". Ms Jenna was quick to add how the children's responses encouraged the use of music throughout the children's school day because "you know when they like it, they come up and say their stories and then during lunch...and outside...". 


\subsection{The Role of Music in Children's Routines}

Soon enough it became clear that early literacy development was not the only overriding gain for the children. Six weeks into the music intervention, Ms Judith noticed that some of the least interactive children found an outlet in music to express themselves and make their voice heard. Bryson, a boy of small posture, who had speech challenges and many times displayed inappropriate behaviours during circle time (such as picking other children, pushing them, or taking their things) said "I don't want to tell you I can sing a song" and took the microphone (one of the materials used for the music activities) and asked to share his mom's favourite song. Ms Jenna and Ms Judith celebrated the moment.

Ms Judith said that " (children) opened up during circle time...they are social, they want to talk...(but) the mic gave him something to hide behind it...(Bryson) opened up regarding music circle and being more interactive... he is big in: I got to use the mic". Reflecting further on Bryson's actions, Ms Jenna noted how "we were having many behavioural problems and at times he would calm down...at times not all the times...he would sat down and actually watch you and sing, and he enjoyed that time, he really did!".

During play time, Mat, a quiet boy who usually played on his own took a leading role leading his friends in a marching band performance. Gradually, the marching band became part of their play routine and the children started doing more of it in order to transition to their circle time after the free play period was over.

The researcher was able to observe how children found a new venue in music in order to explore their potentials and share their accomplishments. At the book centre they grabbed the music story books and sang/read them to each other. The alphabet dance became part of their play routines during free play time and many times they asked to perform their name song and draw the letters on the air in front of their friends, family members, and the adults in the room. It seemed that music activities allowed them to express themselves, engage with their friends, and practice important early literacy skills at the same time. When the researcher asked Bethany, a 4 year old girl who had challenges recalling information and participating in the circle time, what she was humming, Bethany replied to the researcher with a big smile: "you know what? I am learning things".

\section{Discussion}

Building upon the central role that music has in young children's lives, this study provides an example on how music can help foster motivation, engagement and academic growth for all children in early childhood settings. The use of music allowed teachers to modify activities in order to meet the diverse academic and emotional needs of children in their group while they encouraged peer support and collaboration. As such, music activities functioned as an environmental adaptation, when intentionally embedded in the daily classroom routines. They allowed young children to identify their strengths, participate in the learning process at the level of their abilities, and share their interests in an interactive and appropriate manner. At the same time, the children's responses mutually affected the teachers' choices and priorities relevant to teaching. One might say that embedding music in the school's daily routines created a new culture in which the social and emotional development of young children balanced with their academic growth through satisfactory and joyful music experiences.

Moreover, the findings of this research pinpoint to an important observation in relation to teacher's perspectives on the content and process of teaching. Research indicates that preschool teachers may have strong convictions regarding students' outcomes that relate to maturations beliefs (Powell, Diamond, Bojczyk, and Gerde, 2009). Furthermore, they may have restrictions that pinpoint to the structure and the program of each center and to various dimensions of young children's lives. Eventually, these may affect their teaching choices and the opportunities for collaboration with coaches and consultants (Brown and Sumsion, 2007; Friesen and Butera, 2012). For example, the classroom teacher was sceptical about meaning-focused skills and she responded with initial resistance to the literacy activities presented in MELody because she was aware of the social and emotional needs of the children in her group. The children's positive responses to the music activities along with the flexibility of the intervention (that is, the use of music at different times of the day) opened up possibilities for providing instructions with respect to the teachers' schedule and her priorities. More importantly, the appealing medium of music added flexibility to the instructional time while more opportunities for learning were offered during different times of the day (including recess, transitions, and during free-play) in a meaningful, contextual, and a joyful manner.

Although this research did not aim to explore professional development for early childhood educators, it may have some far-reaching implications for the professional learning of teachers. Early childhood educators, especially at Head Start schools, assume different roles to meet the diverse needs of children in their classes. The intentional use of music may be one strategy that allows them to capitalize on the resources available in the classroom and the cultural background they already share with their students. Music activities with a learning focus may build on teachers' capacity to promote early literacy instruction while they can be actively involved in the design and the content of the music model. This approach may ensure respect to the expertise of the teachers and offer opportunities for a collaborative iterative process among the teachers and the researcher.

This study holds promising results but also has limitations. The small sample and the profile of the participants 
does not allow for generalizations of the findings and calls for replications with bigger samples and more teachers involved. The development of a manual to accompany MELody along with materials to document fidelity of implementation and ongoing self-evaluation and self-reflection from the teachers would lead to more precise documentation of the efficacy of using music as a teaching strategy within early childhood settings. Observations and interviews are critical in exploring the teachers' perspectives. Future studies need to implement other instruments to explore teachers' knowledge and strategies in the classroom, such as longer periods of observation, focus groups and concept maps. Additionally, standardized measures may be implemented to assess the children's growth in specific early literacy areas since this was one of the goals of the project.

The researcher's presence in the classroom and the relationships formed have probably affected the use of MELody and the findings. Outlining the main components of the teacher-researcher collaboration may allow for a wider implementation of the study in different early childhood settings. Finally, future research may focus more on specific aspects of music activities and how they may promote young children's early literacy abilities and engagement in the classroom routines.

Future research might investigate the effects of a music curriculum in inclusive early childhood settings, (combining quantitative and qualitative measures), to allow for a deeper understanding of the possible benefits of music in children's engagement and early literacy abilities. Also, it would be important to research early childhood educators' needs and the supports in place to inform professional development programs. Large cohort studies and longitudinal studies might follow-up to investigate the potential role of music in promoting engagement and academic growth of all children in early childhood settings.

\section{References}

Anvari, SH, Trainor, LJ, Woodside J and Levy B A (2002) Relations among musical skills, phonological processing and early reading ability in preschool children. Journal of Experimental Psychology, 83(2), 111130.

Barrett MS (2006) Inventing songs, inventing worlds: The 'genesis' of creative thought and activity in young children's lives. International Journal of Early Years Education, 14(3), 201-220.

Brantlinger E, Jimenez R, Klingner J, Pugach M and Richardson V (2005). Qualitative studies in special education. Exceptional Children, 71, 195-207.

Braun V and Clarke V. (2006). Using thematic analysis in psychology. Qualitative Research in Psychology, 3, $77-$ 101.

Brofenbrenner U (1977) Toward an Experimental Ecology of Human Development. American Psychologist, 32, 7, 513-31.

Brown K and Sumsion J (2007) Voices from the other side of the fence: Early childhood teachers' experiences with mandatory regulatory requirements. Contemporary Issues in Early Childhood, 8(1), 30-49. doi:10.2304/ ciec.2007.8.1.30

Campbell PS (2010) Songs in their heads: Music and its meaning in children's lives. New York, NY: Oxford University Press.

Catts HW, Fey ME, Tomblin JB and Zhang X (2002) A longitudinal investigation of reading outcomes in children with language impairments. Journal of Speech, Language and Hearing Research, 45(6), 1142.

Custodero LA (2002) Seeking challenge, finding skill: Flow experience and music education. Arts Education Policy Review, 103(3), 3-9

Darrow AA, Cassidy JW, Flowers PJ, Register D, Sims W, Standley JM and Swedberg O (2009) Enhancing literacy in the second grade five related studies using the register music/reading curriculum. Update: Applications of Research in Music Education, 27(2), 12-26.

Denton K, West J and Walston J (2003) Reading--Young Children's Achievement and Classroom Experiences: Findings from the Condition of Education. National Center for Educational Statistics, Washington, DC.

Diamond KE, Justice LM, Siegler RS and Snyder PA (2013) Synthesis of IES Research on Early Intervention and Early Childhood Education. NCSER 2013-3001. National Center for Special Education Research.

Dixon-Krauss L, Januszka C M and Chae CH (2010) Development of the dialogic reading inventory of parentchild book reading. Journal of Research in Childhood Education, 24(3), 266-277.

Duncan LG and Seymour PH (2000) Socio-economic differences in foundation-level literacy. British Journal of Psychology, 91(2), 145-166.

Fredricks JA, Blumenfeld PC and Paris AH (2004) School engagement: Potential of the concept, state of the evidence. Review of Educational Research, 74(1), 59-109.

Friesen A and Butera G (2012) "You introduce all of the alphabet ... But I do not think it should be the main focus": Exploring early educators' decisions about reading instruction. Early Childhood Education Journal, 40, 361-368. doi:10.1007/s10643-012-0530-0

Graue ME and Walsh DJ (1995) Children in context: Interpreting the here and now of children's lives. Qualitative research in early childhood settings, 135-154. 
Goldstein H(2011) Knowing what to teach provides a roadmap for early literacy intervention. Journal of Early Intervention, 33(4), 268-280. doi:10.1177/1053815111429464Greenwood, C. R., Horton, B. T., and Utley, C. A. (2002). Academic engagement: Current perspectives on research and practice. School Psychology Review, 31(3), 328-349

Hallam S (2010) The power of music: its impact on the intellectual, social and personal development of children and young people. International Journal of Music Education, 28(3), 269-289.

Hart B and Risley TR (2003) The early catastrophe: The 30 million word gap by age 3. American Educator, 27(1), 4-9.

Heyworth JN (2013) Developing Social Skills Through Music: The Impact of General Classroom Music in an Australian Lower Socio-Economic Area Primary School. Childhood Education, 89(4), 234-242

Horn E and Banerjee R (2009) Understanding curriculum modifications and embedded learning opportunities in the context of supporting all children's success. Language,Speech, and Hearing Services in Schools, 40(4), 406-415.

Isenberg J and Jalongo M (2001) Creative expression and play in early years. 3rd ed. New Jersey: Prentice Hall.

Jackson R, McCoy A, Pistorino C, Wilkinson A, Burghardt J, Clark, M, Schmidt SR (2007) National evaluation of Early Reading First: Final report to Congress. Washington, DC: Institute of Education Sciences, U.S. Department of Education.

Klingner JK, Boardman AG and Mcmaster KL (2013) What does it take to scale up and sustain evidence-based practices?. Exceptional Children, 79(2), 195-211.

Lessard A and Bolduc J (2011) Links between Musical learning and reading for first to third grade students: A literature review. International Journal of Humanities and Social Science, 1(7), 109-118.

Lieber J, Horn E, Palmer Sand Fleming K (2008) Access to the general education curriculum for preschoolers with disabilities: Children's school success. Exceptionality, 16(1), 18-32.

Marulis LM and Neuman SB (2010) The effects of vocabulary intervention on young children's word learning: A meta-analysis. Review of educational research, 80(3), 300-335.

Massey DS (2007) Categorically unequal: The American stratification system. New York, NY: Russell Sage Foundation.

Maxwell JA (2005) Qualitative Research Design: An Interactive Approach. Sage Publications: Thousand Oaks, $\mathrm{CA}$

McCardle P, Scarborough HS and Catts HW (2001) Predicting, explaining, and preventing children's reading difficulties. Learning Disabilities Research and Practice, 16(4), 230-239.

McCardle P and Chhabra V (2004) The accumulation of evidence: A continuing process. In S McCardle P and E Albro E (Eds) Introduction to this special issue: Reading comprehension assessment. The voice of evidence in reading research, (pp. 463-478).

McCormick L, Noonan MJ and Heck R (1998) Variables affecting engagement in inclusive preschool classrooms. Journal of Early Intervention, 21(2), 160-176

McWilliam RA and Bailey DB (1995) Effects of classroom social structure and disability on engagement. Topics in Early Childhood Special Education, 15(2), 123-147.

McWilliam RA (2000) Scale for Teachers' Assessment of Routines Engagement (STARE). Chapel Hill, NC: University of North Carolina, FPG Child Development

McWilliam R A and Casey AM (2008) Engagement of every child in the preschool classroom. Baltimore, MD: Paul H. Brookes Publication Company.

Mol S and Neuman SB (2014) Sharing information books with kindergartners: The role of parents' extra-textual talk and socio-economic status. Early Childhood Research Quarterly, 29, 399-410. http://dx.doi .org/10.1016/j.ecresq.2014.04.001

National Center for Education Statistics (2009) The Nation's Report Card: Reading 2009 (Report No: NCES 2010-458). Washington, DC: Institute of Education Sciences, U.S. Department of Education. National Head Start Association (2012). About Head Start. Retrieved from: http://eclkc.ohs.acf.hhs.gov/hslc/hs/about

Neuman SB and Carta J (2011) Advancing the measurement of quality for early childhood programs that support early language and literacy development. In M. Zaslow, I. Martinez-Beck, K. Tout, and K. Halle (Eds.), Quality measurement in early childhood settings (pp. 220-255). Baltimore, MD: Brookes.

Neuman SB (2006) N is for nonsensical. Educational Leadership, 64(2), 28-31.

Palmer S (2004) Hear hear. Nursery World, October 30, 25

Park J, Turnbull AP and Turnbull HR (2002) Impacts of poverty on quality of life in families of children with disabilities. Exceptional Children, 68(2), 151-170.

Pianta RC, Mashburn AJ, Downer JT, Hamre BK and Justice L (2008) Effects of Web-mediated professional development resources on teacher-child interactions in pre-kindergarten classrooms. Early Childhood Research Quarterly, 23(4), 431-451. doi:10.1016/j.ecresq.2008.02.001

Pound L and Harrison C (2003) Supporting musical development in the early years. Buckingham, England: Open 
University Press.

Powell DR, Burchinal MR, File N and Kontos S (2008) An eco-behavioral analysis of children's engagement in urban public school preschool classrooms. Early Childhood Research Quarterly, 23(1), 108-123.

Powell DR, Diamond KE, Bojczyk KE and Gerde HK (2009) Head Start teachers' perspectives on early literacy. Journal of Literacy Research, 40(4), 422-460. doi:10.1080/10862960802637612

Register D (2001) The effects of an early intervention music curriculum on prereading/writing. Journal of Music Therapy, 38(3), 239-248.

Ridley SM, McWilliam RA and Oates CS (2000) Observed engagement as an indicator of child care program quality. Early Education and Development, 11(2), 133-146.

Rogoff B (2003) The cultural nature of human development. New York, NY: Oxford University Press.

Sandall SR, McLean ME, Smith BJ and Council for Exceptional Children. (2000) DEC recommended practices in early intervention/early childhood special education. Longmont, CO: Sopris West

Standley JM (2008) Does music instruction help children learn to read? Evidence of a meta-analysis. Update: Applications of Research in Music Education, 27(1), 17-32.

Sumsion J (2004) Early childhood teachers' constructions of their resilience and thriving: A continuing investigation. International Journal of Early Years Education, 12(3), 275-290.

Trevarthen C and Malloch SN (2000) The dance of wellbeing: Defining the musical therapeutic effect. Nordic Journal of Music Therapy, 9(2), 3-17.

U.S. Department of Health and Human Services (2017) Head Start performance fact sheet. Retrieved February10,2018from https://eclkc.ohs.acf.hhs.gov/sites/default/files/pdf/hs-program-fact-sheet-2017_0.pdf

Vaiouli, P., \& Andreou, G. (2017). Language development of young children with Autism: A narrative review of research in music. Communication Disorders Quarterly. Advance online publication ahead of print release. doi:1525740117705117

Vaiouli, P., Friesen, A. (2016). The magic of music: Using songs to engage young children with autism spectrum disorders in early literacy activities with their peers. Childhood Education. 92(2), 126-133

Vaiouli, P., Grimmet, K., Ruich, L., (2015). "Bill is now singing": Joint engagement and the emergence of social communication of three young children with autism. Autism, 19 (1), 73-83

Vaiouli, P., Ogle, L., (2015). Music strategies to promote engagement and academic growth of young children with ASD in the inclusive classroom. Young Exceptional Children, 18(2), 19-28

Vygotsky L S and Cole M (1978) Mind in society: The development of higher psychological processes. Cambridge, MA: Harvard University Press.

Warren SF and Kaiser AP (1986) Incidental language teaching: A critical review. Journal of Speech and Hearing Disorders, 51(4), 291-299.

Warren SF, Yoder PJ, Gazdag GE, Kim K and Jones HA (1993) Facilitating prelinguistic communication skills in young children with developmental delay. Journal of Speech, Language and Hearing Research, 36(1), 8397.

Welch G and McPherson G (2012). Introduction and Commentary: Music Education and the Role of Music in People's Lives. In McPherson, G. and Welch, G. (Eds.) The Oxford Handbook of Music Education. Vol 1. (pp. 5-20). New York, Oxford University Press

Wolery M and Hemmeter M L (2011). Classroom instruction: Background, assumptions, and challenges. Journal of Early Intervention, 33(4), 371-380.

Whitehurst GJ and Lonigan CJ (1998). Child development and emergent literacy. Child Development, 69(3), 848872.

Whitehurst GJ and Lonigan CJ (2001) Emergent literacy: Development from prereaders to readers. In S. Neuman and D. Dickinson (Eds.), Handbook of early literacy research (pp. 19-30). New York, NY: The Guilford Press

Yin, R. K. (2003). Case study research: Design and methods (3rd ed.). Thousand Oaks, CA: Sage.

Young S (2003) Music with the under fours. Abingdon: Routledge Falmer.

Young S and Ilari B (2012) Musical Participation from Birth to Three: Toward a Global Perspective. In G. MacPherson and G. Welsh (Eds.), The Oxford Handbook of Music Education, Vol. 1. Oxford: Oxford University Press.

Youth Music (2006) Turning their ears on ... keeping their ears open - Exploring the impact of musical activities on the develop ment of pre-school age children. Northumberland: Northumbria University.

Youth Music (2007) Early years music making: an introduction for early years practitioners. London: National Foundation for Youth Music.

Ziolkowski RA and Goldstein H (2008) Effects of an embedded phonological awareness intervention during repeated book reading on preschool children with language delays. Journal of Early Intervention, 31(1), 6790. Baltimore; Brooks Publishing Company 
Potheini Vaiouli, PhD, is a Special Scientist for research at the Center for Applied Neuroscience, University of Cyprus. She holds an MA in music therapy (New York University) and a PhD in special education (Indiana University, Bloomington). Her research interests converge around social, emotional, and academic growth of young children with autism and other neurodevelopmental disabilities. Her research projects have focused primarily on the role of music in social communication skills (preverbal and verbal communication) and emotional development of young children with autism and their families. Potheini is experienced in mixed methods research design and has extensive experience teaching and supervising undergraduate and graduate students.

Kharon Grimmet, PhD, is a Clinical Assistant Professor and Coordinator of Purdue University's Online Master of Science in Special Education Program. Double majoring in elementary and special education, she received her bachelor's degree from Indiana Wesleyan University, a master's degree in special education (severe disabilities) from Ball State University, and her doctoral degree from Indiana University. Kharon's research interests include teacher education, education policy, transition, and quality of life of adults with intellectual disability. With more than 16 years of experience, Kharon believes that in order to truly invest in our students, we must first invest in our teachers.

Table 1. Music Strategies to Promote Children's Engagement and Early Literacy Skills

\begin{tabular}{|c|c|c|c|}
\hline $\begin{array}{l}\text { Recommended Practices } \\
\text { for Young Children }\end{array}$ & $\begin{array}{c}\text { Music } \\
\text { Component }\end{array}$ & Activity Procedures & Specific Skills \\
\hline \multirow[t]{2}{*}{$\begin{array}{l}\text { Interactions with Peers } \\
\text { integrated through natural } \\
\text { everyday experiences }\end{array}$} & $\begin{array}{l}\text { Pre-composed } \\
\text { songs }\end{array}$ & $\begin{array}{l}\text { Embed songs in daily routines } \\
\text { to mark beginning/end of an } \\
\text { activity and remind expected } \\
\text { behaviors }\end{array}$ & Engagement \\
\hline & Action songs & $\begin{array}{l}\text { Invite children to identify } \\
\text { actions that match the song } \\
\text { rhythm (i.e. clapping hands, } \\
\text { striking a drum, jumping ) }\end{array}$ & $\begin{array}{l}\text { Sound Sensitivity } \\
\text { Rhyming }\end{array}$ \\
\hline $\begin{array}{l}\text { Systematic Delivery of } \\
\text { Instruction }\end{array}$ & $\begin{array}{l}\text { Pre-composed } \\
\quad \text { songs } \\
\text { Children's } \\
\text { Invented songs }\end{array}$ & $\begin{array}{l}\text { Ask questions about the song } \\
\text { content } \\
\text { Sing and change the lyrics } \\
\text { according to the learning focus }\end{array}$ & $\begin{array}{l}\text { Vocabulary } \\
\text { Development } \\
\text { Comprehension } \\
\text { Phonological } \\
\text { Awareness }\end{array}$ \\
\hline \multirow[t]{2}{*}{$\begin{array}{l}\text { Engagement by enhancing } \\
\text { child motivation and } \\
\text { initiation }\end{array}$} & $\begin{array}{l}\text { Pre-composed } \\
\text { songs }\end{array}$ & $\begin{array}{l}\text { Move to the music and dance with } \\
\text { their peers (traditional folk dances, } \\
\text { contemporary music, classical } \\
\text { waltzes) }\end{array}$ & $\begin{array}{l}\text { Peer Interactions } \\
\text { Engagement }\end{array}$ \\
\hline & Action Songs & $\begin{array}{l}\text { Act out certain parts of the song } \\
\text { while singing } \\
\text { Match different sounds } \\
\text { Form a band and perform for peers }\end{array}$ & Sound Sensitivity \\
\hline
\end{tabular}

